Artikel Penelitian

\title{
Profil Penderita Leukemia Mieloblastik Akut di Bagian Penyakit Dalam RSUP Dr. M. Djamil Padang
}

\author{
Bayu Rahmadin ${ }^{1}$, Irza Wahid ${ }^{2}$, Rismawati Yaswir ${ }^{3}$
}

\begin{abstract}
Abstrak
Jenis leukemia yang paling umum ditemukan pada orang dewasa adalah leukemia mieloblastik akut. Tujuan penelitian ini adalah untuk mengetahui profil penderita Leukemia Mieloblastik Akut di bagian Penyakit Dalam RSUP Dr. M. Djamil Padang. Penelitian ini bersifat deskriptif retrospektif yang dilaksanakan pada Februari - Mei 2015. Populasi penelitian ini adalah semua pasien leukemia mieloblastik akut yang dirawat di bagian penyakit dalam RSUP Dr. M. Djamil Padang antara Januari 2014 sampai Desember 2014. Sampel untuk penelitian ini adalah bagian dari populasi yang memenuhi kriteria inklusi yaitu berjumlah 35 orang. Data diambil melalui rekam medis dan pengolahan data dilakukan secara manual. Hasil penelitian ditemukan pasien leukemia mieloblastik akut terbanyak pada kelompok umur 20-39 tahun sebanyak 16 orang (45,71\%). Berdasarkan jenis kelamin, lebih banyak ditemukan pada perempuan sebanyak 18 orang (51,43\%). Berdasarkan klasifikasi French-American-British (FAB), tipe leukemia mieloblastik akut yang terbanyak yaitu tipe $\mathrm{M}_{4}$ sebanyak 20 orang (57,14\%). Sebanyak 17 orang mengalami anemia berat $(48,57 \%)$. Terdapat 21 orang mengalami hiperleukositosis (60\%). Seluruh pasien leukemia mieloblastik akut mengalami trombositopenia (100\%). Terdapat 32 orang dengan presentasi blast $>30 \%(91,43 \%)$.
\end{abstract}

Kata kunci: leukemia mieloblastik akut, leukositosis, anemia, trombositopenia

\begin{abstract}
The most common type of leukemia in adults is acute myeloid leukemia. The objective of this study was to determine profile of patients with acute myeloid leukemia in Internal Medicine Department of Dr. M. Djamil Hospital Padang. This research is retrospective descriptive design conducted in February - May 2015. The population was all acute myeloid leukemia patients who were treated in Internal Medicine Department of Dr. M. Djamil Hospital Padang since January until December 2014. Samples for this research is the part of population that fulfill inclusion criteria, amounting to 35 people. Data retrieved through medical records and data processing is done manually. The result showed most of acute myeloid leukemia patients founded at the age of 20-39 years old as many as 16 people (45.71\%). Female patients were18 people (51.43\%). Based on French-American-British (FAB) classification, most of acute myeloid leukemia patients was M4 type as many as 20 people $(57,14 \%)$. There were 17 people have severe anemia (48.57\%). There were 21 people have hyper leukocytosis (60\%). All acute myeloid leukemia patients had thrombocytopenia (100\%). There were 32 people with blast presentation $>30 \%$ (91.43\%).
\end{abstract}

Keywords: acute myeloid leukemia, leukocytosis, anemia, thrombocytopenia

Affiliasi penulis: 1. Prodi Profesi Dokter FK Unand (Faklutas Kedokteran Universitas Andalas Padang) 2. Bagian IImu Penyakit Dalam FK Unand, 3. Bagian Patologi Klinik FK Unand Korespondensi: Bayu Rahmadin,Email: rahmadin23@gmail.com Telp: 0812803232

\section{PENDAHULUAN}

Leukemia adalah suatu penyakit neoplasma yang mengenai sel dari sistem hematolimfopoietik dengan karakteristik infiltrasi sel leukosit ke darah, sumsum tulang, dan jaringan lain. Hal ini dapat menyebabkan terganggunya homeostasis tubuh sehingga terjadi gangguan pada berbagai sistem organ. ${ }^{1}$ 
Angka kejadian leukemia merupakan salah satu jenis kanker yang apabila tidak dideteksi secara dini bisa berakibat sangat fatal yaitu berupa kematian. Angka kejadian leukemia di Eropa adalah13/100.000 penduduk per tahunnya. Insiden leukemia sendiri $2,8 \%$ dari seluruh jenis kanker yang ada. ${ }^{2}$ Di Asia khususnya China, menurut data tahun 1986-1989, insiden leukemia terjadi sekitar 2,67/100.000, mendekati Negara Asia lainnya. ${ }^{3} \mathrm{Di}$ Indonesia angka kejadian leukemia terus meningkat setiap tahunnya. Berdasarkan data statistik rumah sakit dalam Sistem Informasi Rumah Sakit (SIRS) tahun 2006, kasus leukemia $(5,93 \%)$ berada pada peringkat kelima setelah kanker payudara, kanker leher rahim, kanker hati dan saluran empedu intrahepatik, limfoma nonHodgkin dari seluruh pasien kanker rawat inap rumah sakit di Indonesia. ${ }^{4}$ Khusus di RSUP Dr. M. Djamil Padang ditemukan 56 kasus pada tahun 1986-1990 menjadi 193 kasus pada tahun 1991-1998.,6

Leukemia dibagi menjadi empat tipe utama yaitu leukemia mieloblastik akut (LMA), leukemia limfositik akut (LLA), leukemia mieloisitik kronik (LMK), serta leukemia limfositik kronik (LLK). Ini didasarkan pada asal sel dan tipe sel yang mendominasi sumsum tulang. Berdasarkan sel asal leukemia ada dua yaitu mieloid serta limfoid. Pada leukemia akut tipe sel yang mendominasi adalah sel leukosit yang imatur. Pada leukemia kronik terjadi penumpukan sel leukosit yang sudah matur. ${ }^{7}$

Pada tahun 2005-2009, LMA rata-rata didiagnosis pada usia 66 tahun dan rata-rata terjadi kematian pada usia 72 tahun. Ini yang menyebabkan pentingnya diagnosis dini dari penyakit Leukemia khususnya LMA sehingga angka umur yang terdiagnosa menjadi turun dan terapi bisa lebih efektif serta prognosis yang lebih baik untuk penderita LMA. ${ }^{8}$

Berdasarkan hal diatas, perlu diteliti profil penderita leukemia mieloblastik akut yang dirawat di bagian Penyakit Dalam RSUP Dr. M. Djamil Padang selama tahun 2014.
METODE

Penelitian ini bersifat deskriptif dengan desain deskriptif retrospektif yang dilaksanakan pada Februari Mei 2015. Populasi dari penelitian ini adalah semua pasien LMA di bagian penyakit dalam RSUP Dr. M. Djamil Padang antara Januari 2014 sampai Desember 2014. Sampel untuk penelitian ini adalah bagian dari populasi yang memenuhi kriteria inklusi dan ekslusi berjumlah 35 orang. Instrumen yang digunakan pada penelitian ini adalah data sekunder yang diperoleh dari Instalasi Rekam Medis RSUP Dr. M. Djamil Padang dan pengolahan data dilakukan secara manual.

\section{HASIL}

Tabel 1. Distribusi penderita leukemia mieloblastik akut di bagian Penyakit Dalam RSUP Dr. M. Djamil Padang berdasarkan usia.

\begin{tabular}{ccc}
\hline Usia (tahun) & $\mathbf{f}$ & $\%$ \\
\hline$<20$ & 3 & 8,57 \\
$20-39$ & 16 & 45,71 \\
$40-59$ & 14 & 40 \\
$\geq 60$ & 2 & 5,71 \\
\hline $\mathrm{n}$ & 35 & 100 \\
\hline
\end{tabular}

Tabel 1 memperlihatkan bahwa jumlah pasien leukemia mieloblastik akut yang berusia <20 tahun sebanyak 3 orang (8,57\%), pada usia 20-39 tahun sebanyak 16 orang $(45,71 \%)$, pada usia $40-59$ tahun sebanyak 14 orang (40\%), dan pada pasien dengan usia $\geq 60$ tahun sebanyak 2 orang $(5,71 \%)$.

Tabel 2. Distribusi penderita leukemia mieloblastik akut di bagian Penyakit Dalam RSUP Dr. M. Djamil Padang berdasarkan jenis kelamin.

\begin{tabular}{ccc}
\hline Jenis kelamin & $\mathbf{f}$ & $\%$ \\
\hline Laki-laki & 17 & 48,57 \\
Perempuan & 18 & 51,43 \\
\hline $\mathrm{n}$ & 35 & 100
\end{tabular}


Tabel 2 memperlihatkan bahwa jumlah pasien leukemia mieloblastik akut yang berjenis kelamin lakilaki sebanyak 17 orang $(48,57 \%)$ dan pasien dengan jenis kelamin perempuan sebanyak 18 orang $(51,43 \%)$.

Tabel 3. Distribusi penderita leukemia mieloblastik akut di bagian Penyakit Dalam RSUP Dr. M. Djamil Padang berdasarkan klasifikasi FAB.

\begin{tabular}{ccc}
\hline Jenis LMA & $\mathbf{f}$ & $\%$ \\
\hline$M_{0}$ & 1 & 2,86 \\
$M_{1}$ & 0 & 0 \\
$M_{2}$ & 3 & 8,57 \\
$M_{3}$ & 2 & 5,71 \\
$M_{4}$ & 20 & 57,14 \\
$M_{5}$ & 8 & 22,86 \\
$M_{6}$ & 1 & 2,86 \\
$M_{7}$ & 0 & 0 \\
\hline$n$ & 35 & 100
\end{tabular}

Tabel 3 memperlihatkan bahwa jumlah penderita leukemia mieloblastik akut dengan tipe $M_{0}$ sebanyak 1 orang (2,86\%), tipe $M_{2}$ sebanyak 3 orang $(8,57 \%)$, tipe $M_{3}$ sebanyak 2 orang $(5,71 \%)$, tipe $M_{4}$ sebanyak 20 orang $(57,14 \%)$, tipe $M_{5}$ sebanyak 8 orang $(22,86 \%)$, dan tipe $M_{6}$ cuma 1 orang $(2,86 \%)$.

Tabel 4. Distribusi penderita leukemia mieloblastik akut di bagian Penyakit Dalam RSUP Dr. M. Djamil Padang berdasarkankadar hemoglobin

\begin{tabular}{ccc}
\hline Kadar $\mathbf{H b}(\mathbf{g} / \mathbf{d} \mathbf{l})$ & $\mathbf{f}$ & $\%$ \\
\hline$<6$ & 17 & 48,57 \\
$6-7,9$ & 11 & 31,43 \\
$8-9,9$ & 4 & 11,43 \\
$10-13$ & 3 & 8,57 \\
\hline $\mathrm{n}$ & 35 & 100 \\
\hline
\end{tabular}

Tabel 4. memperlihatkan bahwa terdapat 17 pasien leukemia mieloblastik akut yang mengalami anemia berat $(48,57 \%), 11$ orang mengalami anemia sedang $(31,43 \%), 4$ orang mengalami anemia ringan $(11,43 \%)$, dan 3 anemia ringan sekali $(8,57 \%)$.
Tabel 5. Distribusi penderita leukemia mieloblastik akut di bagian Penyakit Dalam RSUP Dr. M. Djamil Padang berdasarkan jumlah leukosit

\begin{tabular}{ccc}
\hline Jumlah Leukosit $/ \mathbf{m m}^{3}$ & $\mathbf{f}$ & $\%$ \\
\hline$<10.000$ & 5 & 14,29 \\
$10.000-50.000$ & 9 & 25,71 \\
$>50.000$ & 21 & 60 \\
\hline $\mathrm{n}$ & 35 & 100 \\
\hline
\end{tabular}

Tabel 5 memperlihatkan bahwa terdapat 9 pasien leukemia mieloblastik akut dengan leukosit 10.000-50.000 (25,71\%), 21 pasien dengan leukosit $>50.000(60 \%)$, dan 5 pasien dengan leukosit $<10.000$ $(14,29 \%)$.

Tabel 6. Distribusi penderita leukemia mieloblastik akut di bagian Penyakit Dalam RSUP Dr. M. Djamil Padang berdasarkan jumlah trombosit

\begin{tabular}{ccc}
\hline Jumlah trombosit $/ \mathrm{mm}^{3}$ & $\mathbf{f}$ & $\%$ \\
\hline$<150.000$ & 35 & 100 \\
$150.000-400.000$ & 0 & 0 \\
$>400.000$ & 0 & 0 \\
\hline $\mathrm{n}$ & 35 & 100 \\
\hline
\end{tabular}

Tabel 6 memperlihatkan bahwa seluruh pasien leukemia mieloblastik akut mengalami trombositopenia (100\%).

Tabel 7. Distribusi penderita leukemia mieloblastik akut di bagian Penyakit Dalam RSUP Dr. M. Djamil Padang berdasarkan presentasi blast

\begin{tabular}{ccc}
\hline Presentasi blast & $\mathbf{f}$ & $\%$ \\
\hline$<30 \%$ & 3 & 8,57 \\
$>30 \%$ & 32 & 91,43 \\
\hline $\mathrm{n}$ & 35 & 100 \\
\hline
\end{tabular}

Tabel 7 memperlihatkan bahwa terdapat 3 orang penderita leukemia mieloblastik akut dengan presentasi blast $<30 \%(8,57 \%)$ dan ada 32 orang dengan presentasi blast $>30 \%(91,43 \%)$. 


\section{PEMBAHASAN}

Distribusi penderita leukemia mieloblastik akut di bagian Penyakit Dalam RSUP Dr. M. Djamil Padang berdasarkan usia dan jenis kelamin.

Menurut Howlander et al (2011) risiko untuk terjadi leukemia mieloblastik akut meningkat sekitar 10 kali lipat dari usia 30-34 tahun sampai usia 65-69 tahun serta mencapai puncak pada usia 80-84 tahun. Dores et al (2012) menyatakan insiden meningkat berbanding lurus dengan meningkatnya usia yaitu sekitar 1,3 kasus per 100.000 penduduk pada usia dibawah 65 tahun menjadi 12,2 kasus per 100.000 penduduk pada usia diatas 65 tahun. Menurut penelitian Simamora (2009) kasus leukemia dengan jenis kelamin laki-laki lebih tinggi dibandingkan pada perempuan (58\%:42\%). Menurut penelitian Mehta et al (2012) pasien leukemia mieloblastik akut berjenis kelamin laki-laki ada sebanyak $59,7 \%$ berbanding dengan pasien berjenis kelamin perempuan yaitu sebanyak 40,3\%. Pada hasil penelitian kejadian terbanyak terjadi pada kelompok usia 20-39 tahun yaitu sebanyak $45,71 \%$ dan sedikit menurun pada kelompok usia 40-59 tahun yaitu sebanyak 40\% sementara pada kelompok usia $\geq 60$ tahun hanya terjadi sebanyak $5,71 \%$. Pada hasil penelitian juga menunjukkan lebih banyak pasien berjenis kelamin perempuan dibandingkan laki-laki. Banyak faktor yang dapat menyebabkan perbedaan temuan penelitian ini diantaranya yaitu faktor kondisi lingkungan yang buruk, gaya hidup masyarakat, serta faktor kondisi kesehatan dan kepedulian terhadap kesehatan masyarakat yang masih rendah serta jumlah sampel yang berbeda dari penelitian sebelumnya dimana mengambil jumlah sampel yang besar. ${ }^{8-11}$

Distribusi penderita leukemia mieloblastik akut di bagian Penyakit Dalam RSUP Dr. M. Djamil Padang berdasarkan klasifikasi French-American-British (FAB).

Kurnianda (2006) menemukan persentase kasus LMA berdasarkan klasifikasi FAB yaitu LMA $M_{0}$ sebanyak 3\%, LMA $M_{1}$ sebanyak 15-20\%, LMA $M_{2}$ sebanyak 25-30\%, LMA M 3 sebanyak 5-10\%, LMA M 4 sebanyak 25-30\%, LMA M $M_{5}$ sebanyak 2-9\%, LMA M6 sebanyak $3-5 \%$, dan LMA M $M_{7}$ sebanyak 3-12\%.
Temuan ini hampir sama dengan hasil penelitian dimana jenis LMA yang paling banyak adalah LMA tipe $M_{4}$. Hasil penelitian sedikit berbeda dengan temuan Mehta et al (2012) yaitu ditemukan persentase terbanyak adalah LMA $\mathrm{M}_{2}$ sebanyak $28,35 \%$, lalu LMA $M_{5} 24,41 \%$, LMA $M_{1} 21,26 \%$, LMA $M_{4} 14,17 \%$, LMA $M_{3}$ 9,45\%, LMA M $1,57 \%$, serta LMA $M_{7}$ sebanyak $0,79 \%$. Perbedaan hasil temuan ini kemungkinan disebabkan oleh jumlah sampel yang berbeda dan pengambilan sampel yang secara acak yang memenuhi kriteria inklusi. ${ }^{11,12}$

FMS-like tyrosine kinase 3 (FLT3) memiliki peranan penting dalam proses leukomogenesis pada pasien leukemia mieloblastik akut, melalui proses regulasi sel hematopoetik, termasuk metabolisme fosfolipid, transkripsi, proliferasi dan apoptosis. Jika terjadi mutasi pada FLT3 akan terjadi peningkatan ekspresi FLT3 yang mengakibatkan terjadinya interaksi antar reseptor FLT3 dengan ligand (FL), sehingga akan terjadi perubahan konformasi, ini menyebabkan terungkapnya reseptor dan pemaparan dari domain dimerisasi. Dimerisasi dari reseptor ini adalah awal dari aktivasi enzim tirosin kinase sehingga menyebabkan fosforilasi berbagai situs domain intraseluler. Ini menyebabkan peningkatan proliferasi sel, penurunan masa hidup sel, penurunan diferensiasi, cell cycle arrest, gangguan apoptosis dan gangguan pertumbuhan sel. Semua gangguan tersebut akan mengakibatkan blokade maturitas sehingga menyebabkan sel mieloblast meningkat dan jumlah leukosit juga meningkat. ${ }^{13,14}$

Pada penelitian Colovic et al (2007) didapatkan hasil mutasi FLT3 terbanyak pada LMA M5. FLT3ligand $(F L)$ diperlukan untuk diferensiasi lengkap dari monosit dan FLT3 terekspresi secara persisten selama proses diferensiasi monosit. Pada penelitian Libura et al (2013), didapatkan hasil ekspresi FLT3 paling tinggi ditemukan pada LMA $M_{4}$ dan LMA $M_{5}$, yang diperkirakan berhubungan dengan kelainan sitogenetik yaitu translokasi kromosom 11q23 yang banyak terjadi pada tipe LMA tersebut. ${ }^{15,16 .}$ Peningkatan ekspresi $F L T 3$ pada LMA $M_{4}$ dan LMA $M_{5}$ yang diperkirakan berhubungan dengan jumlah penderita LMA M4 dan LMA $M_{5}$ yang tinggi yang didapatkan peneliti. 
Distribusi penderita leukemia mieloblastik akut di bagian Penyakit Dalam RSUP Dr. M. Djamil Padang berdasarkan kadar hemoglobin

Hasil penelitian Mehta et al (2012) juga menemukan hasil yang hampir serupa yaitu pasien dengan kadar hemoglobin $<9 \mathrm{gr} / \mathrm{dl}$ ada sebanyak $76,39 \%$ serta pasien dengan kadar hemoglobin $\geq 9$ $\mathrm{gr} / \mathrm{dl}$ hanya $23,61 \%$. $^{11}$

Anemia pada keganasan bisa terjadi salah satunya disebabkan karena respon eritropoetin yang tidak adekuat terhadap anemia akibat efek sitokin seperti Tumor Necrosis Factor (TNF) dan interleukin-1 (IL-1) pada eritropoesis. Anemia ini hanya dapat terkoreksi dengan keberhasilan penyakit yang mendasari. Pada leukemia mieloblastik akut ditemukan kelainan laboratorium berupa anemia yang mula-mula ringan dan semakin berat apabila tidak didiagnosa dan ditatalaksana dengan benar. Kelainan anemia yang terjadi disebabkan tertekannya proses hematopoiesis normal akibat dari proliferasi sel leukosit yang sangat banyak di sumsum tulang. ${ }^{1,3,17}$

Distribusi penderita leukemia mieloblastik akut di bagian Penyakit Dalam RSUP Dr. M. Djamil Padang berdasarkan jumlah leukosit

Penelitian Hu et al (2011) menunjukkan hasil yaitu terdapat $59,5 \%$ kasus mengalami leukositosis serta $40,5 \%$ kasus dengan jumlah leukosit normal atau menurun. ${ }^{18}$

Peningkatan jumlah leukosit disebabkan oleh proses blokade pada pematangan leukosit yaitu sel mielosit yang mengakibatkan menumpuknya sel-sel mielosit muda di sumsum tulang dan bisa menyebar melalui pembuluh darah ke jaringan seperti hati dan limpa. ${ }^{12}$ Penyebab blokade pada pematangan leukosit ini adalah kelainan genetik akibat dari mutasi gen sehingga terjadi peningkatan proliferasi sel dan penurunan masa hidup sel leukosit. ${ }^{19}$

Distribusi penderita leukemia mieloblastik akut di bagian Penyakit Dalam RSUP Dr. M. Djamil Padang berdasarkan jumlah trombosit

Hasil ini serupa dengan Bakta (2003) yaitu pada penderita leukemia mieloblastik akut sering mengalami trombositopenia berat dibawah $1 \times 10^{6} / \mathrm{L}^{2}$ Jumlah trombosit yang menurun pada leukemia merupakan akibat dari infiltrasi ke sumsum tulang atau kemoterapi.Infiltrasi sel leukemik di sumsum tulang menyebabkan sumsum tulang dipenuhi oleh sel leukemik sehingga terjadi penurunan jumlah megakariosit yang mengakibatkan menurunnya produksi trombosit. Kemoterapi pada penderita leukemia menyebabkan kerusakan sumsum tulang yang akan berakibat berkurangnya produksi trombosit. Penyebab lain trombositopenia yaitu karena koagulasi intravaskuler diseminata (KID) dimana sering dihubungkan dengan leukemia promielositik akut (LMA $M_{3}$ ), leukemia mielomonositik akut akut (LMA $M_{4}$ ), dan leukemia mieloblastik akut (LMA $M_{1}$ dan LMA $M_{2}$ ). Penyebabnya adalah karena pelepasan material prokoagulan (tromboplastin like substance) dari blast sel leukemik.Proses imunologis, dan hipersplenisme sekunder terhadap pembesaran limpa juga termasuk sebagai penyebab terjadinya trombositopenia. ${ }^{20}$

Distribusi penderita leukemia mieloblastik akut di bagian Penyakit Dalam RSUP Dr. M. Djamil Padang berdasarkan presentasi blast

Menurut Kurnianda (2006) pada 85\% kasus LMA ditemukan sel-sel blast dalam jumlah yang signifikan di darah tepi. ${ }^{12}$

Pada pasien LMA terjadi blokade maturitas akibat dari kelainan genetik oleh mutasi gen. Mutasi gen pada LMA selain menyebabkan peningkatan proliferasi sel dan penurunan masa hidup sel, juga menyebabkan terganggunya proses diferensiasi sel. ${ }^{19}$

Terganggunya proses diferensiasi sel mielosit akan menyebabkan perkembangan terhenti pada selsel muda (blast) sehingga mengakibatkan terakumulasinya blast di sumsum tulang. Sel-sel muda inilah yang bisa bermigrasi keluar dari sumsum tulang ke darah tepi dan bisa menginfiltrasi ke organ lain seperti kulit dan jaringan lunak. ${ }^{12}$

Keterbatasan pada penelitian ini yaitu pada penelitian ini hanya dilakukan dalam satu tahun dikarenakan jumlah data sekunder sebelum tahun 2014 di instalasi rekam medis yang tidak memadai dan berbeda jauh jumlahnya jika dibandingkan dari tahun 2014 yang masih cukup lengkap. 


\section{SIMPULAN}

Lebih banyak penderita leukemia mieloblastik akut dengan jenis kelamin perempuan dibandingkan laki-laki. Lebih dari separuh penderita leukemia mieloblastik akut mengalami LMA $\mathrm{M}_{4}$

Seluruh penderita leukemia mieloblastik akut mengalami anemia Sebagian besar mengalami hiperleukositosis. Seluruh penderita leukemia mieloblastik akut mengalami trombositopenia. Ditemukan presentasi blast $>30 \%$ pada hampir seluruh darah tepi pasien leukemia mieloblastik akut.

\section{DAFTAR PUSTAKA}

1. Hoffbrand AV, Pettit JE, Moss PAH. Kapita selekta hematologi. Edisi ke-4. Jakarta: EGC; 2005.hlm. 150-66.

2. Baktal M. Hematologi klinik ringkas. Jakarta: EGC; 2003; 117:120-31.

3. Desen W. Buku ajar onkologi klinis. Edisi ke-2. Jakarta: Balai Penerbit FKUI; 2008.hlm.547-98.

4. Departemen Kesehatan RI. Obesitas dan kurang aktivitas fisik menyumbang 30\% kanker. 2009. Tersedia dari: URL: HYPERLINK http://www. indonesia.go.id

5. Yaswir R. Jenis-jenis Leukemia di Laboratorium Patologi Klinik FK Unand/ RSUP M. Djamil Padang. Padang: Bagian Patologi Klinik FKUA Padang. 1990.

6. Marlinda. Gambaran hematologi leukemia nonlimfoblastik akut di RSUP M Djamil Padang periode 1991-1998. Padang: Fakultas Kedokteran Universitas Andalas; 1999.

7. Lowenberg B, Cornelissen JJ, Sonneveld P. Leukemia akut dan kronik. Yogyakarta: Oncology; 1999.hlm.641-8.

8. Howlader N, Noone AM, Krapcho M, Neyman N, Aminou $\mathrm{R}$, Waldron $\mathrm{W}$, et al. SEER Cancer statistics review 1975-2008, National Cancer Institute. Bethesda MD. 2011. Tersedia dari: URL: HYPERLINK http://seer.cancer.gov/csr/1975 2008/

9. Dores GM, Devesa SS, Curtis RE, Linet MS, Morton LM. Acute leukemia incidence and patient survival among children and adults in the United States, 2001-2007. Blood. 2012;119:34.
10. Simamora. Karakteristik penderita leukemia rawat inap di RSUPH Adam Malik Medan tahun 20042007 (skripsi). Medan: Fakultas Kesehatan Masyarakat Universitas Sumatera Utara; 2009.

11. Mehta SV, Shukla SN, Vora HH, Comprehensive FLT3 analysis in Indian Acute myeloid leukemia. J Blood Lymph. 2012;2(1):1-13.

12. Kurnianda J. Leukemia mieloblastik akut. Dalam: Buku Ajar IImu Penyakit Dalam. Jakarta: Interna Publishing. 2006; 706-9.

13. Kusec R, Marusic-Vrsalovic M, Bobetic T, Ostojic S, Mingo $\mathrm{H}$ and Jaksic $\mathrm{B}$. FMS like tyrosine kinase (FLT3) gene ITD mutation in acute myeloid leukemia. Department of Medicine Hematology, Merkur University Hospital Croatia. 2004;1-7.

14. Ozeki K, Kiyoi $H$, Hirose $Y$, Iwai $M$, Ninomiya $M$, Kodera $Y$, et al. Biologic and clinical significance of the FLT3 transcript level in acute myeloid leukemia. Neoplasia, American Society of Hematology. 2004; 103(5):1901-8.

15. Colovic N, Tosic N, Aveic S, Djuric M, Milic N, Bumbasirevic $\mathrm{V}$, et al. Importance of early detection and follow up of FLT3 mutations in patients with acute myeloid leukemia. Ann Hematol. 2007; 86:741-77.

16. Libura M, Asnafi V, Tu A, Delebesse E, Tigaud I, Cymbalista $F$, et al. FLT3 and MLL intragenic abnormalities in AML reflect a common category of genotoxic stress. Blood. 2013;102:2198-204.

17. Bacarea A. Diagnosis of Acute Myeloid Leukaemia. Myeloid Leukemia - Clinical Diagnosis and Treatment. In(Dr Steffen Koschmieder Ed.). InTech. 2012;ISBN 978-953-307-886-1.

18. Hu R, Wu Y, Jiang $X$, Zhang W, Xu L. Clinical symptoms and chemotherapy completion in elderly patients with newly diagnosed acute leukemia: a retrospective comparison study with a younger cohort. BMC Cancer. ISSN: 1471-2407. 2011; 11:224.

19. Takahashi S. Downstream molecular pathways of FLT3 in the pathogenesis of acute myeloid leukemia: biology and therapeutic implications. Journal of hematology \& oncology Japan. 2011;110. 
20. Rofinda ZD. Kelainan hemostasis pada leukemia.

Padang: Fakultas Kedokteran Universitas Andalas;

2012. 